\title{
ANALISIS KEPATUHAN PENYETORAN PAJAK PENGHASILAN BADAN PADA USAHA PENGEPUL BARANG BEKAS ( UD AJENG ) DI DESA BANDUNG, KECAMATAN BANDUNG, KABUPATEN TULUNGAGUNG
}

\author{
Muhammad Hijriatul E, Ajeng Ayu Dwi F, Nur Anita Sari
}

\begin{abstract}
ABSTRAK
Tujuan dari penelitian ini dilakukan untuk mengetahui perhitungan, penyetoran dan pelaporan Pajak Penghasilan Badan yang dilakukan di salah satu usaha yaitu pengepul barang bekas yang telah memiliki surat ijin usaha perdagangan ( SIUP ) di Desa Bandung dengan nama perusahaan UD AJENG dan bagaimana persepsi pemilik pengepul barang bekas UD AJENG terhadap keberadaan persaingan usaha yang semakin ketat. Mengetahui dampak keberadaan persaingan terhadap kepatuhan pembayaran pajak pada usaha pengepul barang bekas. Untuk mencapai tujuan dalam penelitian ini mengunakan jenis penelitian kualitatif dengan metode survei wawancara. Analisis Kualitatif menggunakan reduksi data, penyajian data, dan penarikan kesimpulan. Hasil penelitian menunjukkan, banyaknya pesaing tidak mempengaruhi pengepul barang bekas UD AJENG untuk tidak membayarkan pajak penghasilan badan yang seharusnya dibayarkan walaupun usaha mengalami sedikit penurunan karena adanya persaingan. Tetapi ada juga beberapa oknum yang mengatakan bahwa banyaknya persaingan ini berdampak negatif pada omzet, pendapatan dan jumlah pelanggan sehingga belum tentu semua pengepul barang bekas memiliki kesadaran untuk patuh membayar pajak penghasilan badan yang seharusnya dibayarkan dan diabaikan oleh pemilik usaha pengepul barang bekas tersebut.
\end{abstract}

Kata kunci: Pajak penghasilan badan, pengepul barang bekas, pesaing

\begin{abstract}
The purpose of this study was to determine the calculation, deposit and reporting of Corporate Income Tax carried out in one of the businesses, namely used goods collectors who already have a trading business license (SIUP) in Bandung Village with the company name
\end{abstract}


UD AJENG and how the perception of the owners of used goods collectors is. UD AJENG to the existence of increasingly fierce business competition. Knowing the impact of the existence of competition on tax payment compliance in the business of used goods collectors. To achieve the objectives in this study using a type of qualitative research with interview survey methods. Qualitative analysis uses data reduction, data presentation, and drawing conclusions. The results showed that the number of competitors did not affect the used goods collectors at UD AJENG not to pay the corporate income tax that should have been paid even though the business experienced a slight decline due to competition. However, there are also some people who say that this amount of competition has a negative impact on turnover, income and the number of customers so that not all used goods collectors have the awareness to comply with paying corporate income taxes that should be paid and ignored by the used goods collector business owners.

Keywords: Corporate income tax, used goods collectors, competitors

\section{A. PENDAHULUAN}

Usaha pengepul barang bekas adalah suatu usaha yang biasanya mudah diakses umum dan bersifat lokal. Usaha semacam ini biasanya berlokasi di jalan yang ramai. Usaha pengepul barang bekas dapat ditemukan dikota maupun di desa. Saat ini dapat dirasa bahwa usaha pengepul barang bekas telah menjamur dimana mana baik dikota maupun didesa, dimana kehadiran pengepul barang bekas yang lain tersebut membuat pengepul barang bekas UD AJENG semakin waspada dan mencari ide-ide lain agar usahanya dapat tetap bertahan, penawaran penawaran menarik dari pengepul barang bekas yang lain membuat pelangagan sedikit tergiyur untuk menjual dagangannya di pengepul tersebut, ajakan pelanggan yang satu ke yang lain untuk mencoba menjual barang mereka kepengepul barang bekas yang lain juga menjadi faktor eksternal yang harusnya ada penyelesaiannya, dari hal ini pengepul barang bekas UD AJENG harusnya dapat meningkatkan pelayanan, memberikan bonus-bonus dan penawaran harga yang menarik. Faktor faktor yang membuat bisbis ini menjamur adalah yang pertama faktor peningkatan permintaan dari pabrik-pabrik besar yang akan mendaur ulang barang-barang bekas tersebut. Meningkatnya permintaan barang dari pabrik-pabrik daur ulang membuat pengusaha dibidang pengepul barang bekas ini menjadi terlihat aktif dan 
menimbulkan pemikiran dari masyarakat bahwa bekerja dibidang ini dapat meraup keuntungan yang besar. Faktor kedua yaitu banyaknya sampah yang dapat didaur ulang dan membuat orang-orang berfikir masih banyak peluang untuk sukses dibidang ini. Faktor ketiga yaitu pemikiran orang-orang yang mengira jika modal untuk memulai bisnis pengepul barang bekas ini tidak lah banyak, tetapi kenyataannya perputaran keuangan diusaha ini cukup besar. Akibat munculnya banyak pesaing membuat pengepul barang bekas UD AJENG mulai memutar otak agar pelanggan-pelanggannya tetap memilih untuk menjual barang dagangannya di pengepul barang bekas UD AJENG.

Dampak dari banyaknya pesaing yang muncul membuat pengepul barang bekas UD AJENG menjadi mengalami penurunan sehingga perputaran barang sedikit lebih lama dari pada sebelum adanya pesaing yang mengakibatkan keuntungan menurun. Penelitian ini bertujuan untuk mengetahui pengaruh penurunan omzet terhadap ketaatan pembayaran Pajak Penghasilan Badan. Penelitian ini merupakan penelitian deskriptif kualitatif dengan menggunakan data primer yaitu dengan wawancara kepada pemilik pengepul barang bekas UD AJENG di Desa Bandung, Kecamatan Bandung, Kabupaten Tulungagung. Hasil penelitian ini menggambarkan adanya perubahan penurunan tingkat omzet, keuntungan, dan jumlah pelanggan akibat dari munculnya pengepul barang bekas lain di sekitar tempat berdirinya pengepul barang bekas UD AJENG. Pembahasan yang menarik dikarenakan pertumbuhan pengepul barang bekas bahkan sampai ke daerah pedesaan dinilai sangat cepat, tentu hal ini berhubungan dengan kelangsungan usaha pengepul barang bekas UD AJENG, karena antara pengepul barang bekas UD AJENG dengan pengepul barang bekas yang lain sama-sama menjual dan membeli produk yang sama, namun terkadang ada beberapa pengepul barang bekas yang hanya menerima beberapa jenis barang saja.

Pajak merupakan sumber penerimaan Negara disamping penerimaan dari sumber migas dan non migas. Penghasilan negara adalah berasal dari rakyatnya melalui pungutan pajak, dan atau dari hasil kekayaan alam yang ada dalam negara itu, Penghasilan itu untuk membiayai kepentingan umum yang akhirnya juga mencakup kepentingan pribadi individu seperti kesehatan masyarakat, pendidikan, kesejahteraan dan sebagainya. Jadi, dimana ada kepentingan masyarakat, disana timbul pungutan pajak sehingga pajak adalah senyawa dengan kepentingan umum. (Prabowo, 2019) . pajak muncul Ketika objek pajak bertemu dengan 
subjek pajak dimana objek pajak merupakan penghasilan dan subjek pajak adalah orang atau badan atau organisasi. Ketika objek dan subjek bertemu maka muncul kewajiban membayar pajak. Disamping itu juga penghasilan yang diperoleh atas kegiatan usaha badan akan dikenakan pajak penghasilan badan. Adapun perhitungan untuk mengetahui jumlah pajak badan yang terutang diatur dalam ketentuan PPh Pasal 25.Dalam ketentuan PPh Pasal 25 diatur tentang angsuran pajak penghasilan yang harus dibayar sendiri oleh Wajib Pajak untuk setiap bulan dalam tahun pajak berjalan. Besarnya angsuran pajak dalam tahun berjalan yang harus dilunasi dapat diketahui dengan Pajak Penghasilan yang terutang menurut SPT Tahunan (Walandouw, 2013). Adapun yang menjadi ukuran dalam penerimaan pajak penghasilan badan adalah jumlah pajak penghasilan badan yang disetor, tercapainya target pajak penghasilan badan, kekurangan atau kelebihan pembayaran pajak penghasilan badan. (R. Wandira 2017 Pajak et al., 2016) Jumlah pajak penghasilan badan yang disetor adalah seluruh penerimaan negara yang bersumber dari pajak penghasilan yang telah dilakukan oleh wajib pajak. Tercapainya target pajak penghasilan badan yaitu suatu kondisi yang menggambarkan tercapainya rencana penerimaan pajak penghasilan. Kekurangan atau kelebihan pembayaran pajak penghasilan badan yaitu selisih antara setoran pajak penghasilan yang telah dilakukan oleh wajib pajak penghasilan yang seharusnya terutang.(Fadhillah \& Andi, 2016)

Penelitian ini dilakukan untuk megetahui mengenai kesadaran pembayaran pajak penghasilan badan atas penghasilan dari usaha pengepul barang bekas UD AJENG yang berada di Desa Bandung, kecamatan Bandung,Kabupaten Tulungagung, selain itu tujuan dari penelitian ini untuk mengetahui pengaruh perubahan omzet penjualan terhadap kepatuhan pembayaran pajak penghasilan pasal 23.

\section{B. LANDASAN TEORI}

Pengertian Pajak Menurut Djajadiningrat, pajak adalah kewajiban yang dipaksakan untuk diserahkan kepada negara atas kejadian, perbuatan, atau kedudukan, bukan sebagai hukuman, tanpa mendapat jasa timbal balik langsung demi kesejahteraan umum. (Resmi, 2017)

Pajak memiliki beberapa fungsi diantaranya adalah untuk mengatur perekonomian, mengganggarkan keuangan negara, stabiltias ekonomi, dan redistribusi pendapatan. Sistem 
pemungutan pajak yang diatur oleh pemerintah dengan beberapa cara, yaitu wajib pajak memperhitungkan sendiri pajak yang harus disetor ke kas negara atau biasa disebut Self Assessment System, kemudian terdapat juga proses pemungutan pajak yang besaran pajaknya ditentukan oleh fiskus atau dikenal dengan Official Assessment System, serta terdapat proses pemungutan pajak yang dilakukan oleh pihak ketiga atau disebut denganWitholding Tax System.

\section{A. Pengertian Pajak Penghasilan}

Pajak penghasilan biasa disebut dengan Pajak Penghasilan Pasal 25 atau PPh 25 adalah pajak yang dikenakan untuk orang pribadi, perusahaan atau badan hukum lainnya atas penghasilan yang didapat.

Pajak Penghasilan Pasal 21 yaitu Pajak atas penghasilan sehubungan dengan pekerjaan, jasa, atau kegiatan dengan nama dan dalam bentuk apapun yang diterima atau diperoleh Wajib Pajak orang pribadi dalam negeri sebagaimana diatur dalam Pasal 21 Undang-Undang Pajak Penghasilan. (Halim et al., 2016)

Pajak penghasilan adalah pajak atas setiap tambahan kemampuan ekonomis yang diterima atau diperoleh seseorang ataupun badan usaha (RAHARJO, 2013). Subjek pajak dalam negeri, sebagaimana dimaksud dalam Pasal 21 Undang-Undang Pajak Penghasilan

Dari pengertian di atas dapat disimpulkan bahwa pajak penghasilan adalah pajak yang harus dibayarkan atas pekerjaaan, jasa dan penghasilan lainnya yang dibayarkan kepada negara untuk membiayai pengeluaran negara. Cara Menghitung Pajak Penghasilan Bagi para wajib pajak yang baru saja memulai suatu usaha UKM, proses perhitungan pajak bisa dilakukan dengan cara sebagai berikut :

a) Hitung penghasilan bruto. Di akhir periode akuntansi bisnis, pasti akan ada laporan keuangan yang menyatakan berapa besar penghasilan bisnis laporan keuangan ini atau catatan transaksi yang telah dilakukan dalam bisnis untuk bisa menyusun tahap ini.

b) Hitung penghasilan netto. Setelah memiliki penghasilan bruto, maka Anda bisa menghitung penghasilan bersih perusahaan Anda. tahap ini sama seperti tahap pembuatan laporan keuangan. Membuat laba rugi dan neraca keuangan untuk memperjelas kondisi keuangan perusahaan dalam satu periode. 
c) Hitung Penghasilan Kena Pajak (PKP) Cara menghitung PKP adalah penghasilan bersih selama satu periode akuntansi dikurangi dengan penghasilan tidak kena pajak (PTKP).

d) Hitung PPh yang harus dibayarkan.Setelah mendapatkan nilai PKP, maka Anda hanya perlu mengalikan dengan tarif Pajak PPh dalam setahun. Sedangkan menurut (Harjo, 2013) Berikut dijelaskan 3 (tiga) metode perhitungan :

\section{Gross Method}

Dalam metode ini seluruh Pajak Penghasilan Pasal 21 menjadi tanggungan pekerja/pegawai, sehingga penghasilan yang diterima pekerja/pegawai telah dipotong dengan PPh Pasal 21.

\section{Nett Method}

Dalam metode ini seluruh Pajak Penghasilan Pasal 21 menjadi tanggungan pemberi kerja/perusahaan, sehingga penghasilan yang diterima pekerja utuh dan tidak dipotong dengan PPh Pasal 21. Metode ini mencatat tanggungan PPh Pasal 21 sebagai biaya operasional secara komersial namun beban ini tidak dapat menjadi pengurang penghasilan bruto dalam menentukan Penghasilan Kena Pajak pemberi kerja dalam laba rugi fiskalnya, karena beban ini dianggap sebagai kenikmatan.

\section{Gross Method}

Dalam metode ini pemberi kerja memberikan tunjangan Pajak Penghasilan Pasal 21 kepada pekerja/pegawai yang nilainya sama dengan $\mathrm{PPh}$ Pasal 21 yang dipotong. Metode ini mencatat tanggungan PPh Pasal 21 sebagai biaya operasional fiskal dan dapat menjadi pengurang penghasilan bruto dalam rangka menentukan Penghasilan Kena Pajak pemberi kerja karena PPh Pasal 21 tersebut diberikan dalam bentuk tunjangan yang menambah penghasilan pekerja.

\section{B. Pengertian Pajak Penghasilan Badan}

Pajak penghasilan badan merupakan pemungutan resmi yang dikenakan pada setiap tambahan kemampuan ekonomis yang diterima oleh Wajib Pajak dari suatu badan usaha, baik yang berasal dari dalam negeri maupun luar negeri dalam bentuk dan nama apapun (R. Wandira 2017 Pajak et al., 2016). 
Dari pengertian diatas dapat dikatakan bahwa pajak penghasilan badan adalah pajak yang dikenakan atas penghasilan dari suatu usaha baik usaha dari dalam negri maupun luar negeri.

\section{Cara Menghitung Pajak Penghasilan Badan}

Dalam Undang-Undang No. 36 Tahun 2008 (Susi Dwimulyani, 2014), untuk menghitung pajak penghasilan badan bisa dilakukan dengan beberapa opsi. Opsi yang pertama, yaitu memilih perhitungan apabila badan usaha tersebut tidak memilki pembukuan atau pencatatan, penghasilan kena pajak yaitu pemdapatan bruto dikalikan dengan tarif pajak menggunakan Norma Perhitungan Penghasilan Neto (NPPN). Kemudian opsi kedua, yaitu apabila badan usaha tersebut telah melakukan pembukuan dan pencatatan lengkap maka badan usaha tersebut wajib menghitung penghasilan kena pajaknya berdasarkan pendapatan neto fiskal dikalikan tarif pajak penghasilan badan. Untuk yang memilih kedua opsi tersebut apabila pendapatan brutonya antara Rp 4,8 miliar s/d Rp 50 miliar maka akan mendapatakan fasilitas pengurangan tarif sebesar 25\% dan apabila peredaran brutonya melebihi Rp 50 miliar maka tidak akan dikenakan pengurangan tarif dan tarif pajaknya tunggal sebesar $25 \%$. Berbeda dengan opsi yang terakhir yaitu, wajib pajak badan yang memiliki pendapatan bruto dibawah Rp 4,8 miliar berhak mendapatkan tarif pajak final sebesar 0,5\% sesuai dengan PP No. 46 Tahun 2013.

\section{Pengepul Barang Bekas}

UD AJENG merupakan usaha yang bergerak pada bidang pengepulan barang bekas (sampah) di Desa Bandung Kecamatan Bandung Kabupaten Tulungagung, selaku Bu Wiji Astuti sebagai pemilik usaha ini dengan dibantu oleh beberapa karyawan dan pelanggan ( pencari barang bekas yang menyetorkan barang tersebut ke UD AJENG).

Apa itu pengepul barang bekas? Menurut Kamus Besar Bahasa Indonesia (KBBI), arti kata pengepul adalah tengkulak. Arti lainnya dari pengepul adalah orang yang mengepul. Pengepul berasal dari kata dasar kepul. Pengepul memiliki arti dalam kelas nomina atau kata benda sehingga pengepul dapat menyatakan nama dari seseorang, tempat, atau semua benda dan segala yang dibendakan. Contoh: tugasnya adalah sebagai pengepul cengkih. Sedangkan barang bekas adalah suatu benda yang sudah tidak terpakai lagi namun masih memiliki nilai pakai apabila didaur ulang kembali. Jadi pengepul barang bekas adalah orang yang mengepul 
barang bekas di suatu tempat yang bertujuan untuk dijual kembali jika sudah terkumpul. Jenis barang bekas yang di kumpulkan atau di tampung adalah sampah nonorganik seperti besi tua, limbah/sampah kertas dan plastik, dimana sampah plastik dan sampah lainnya tersebut dikumpulkan dan masih dapat ditingkatkan nilai jualnya dengan proses-proses daur ulang di pabrik daur ulang. Kegiatan ini bertujuan untuk mencari keuntungan berupa materi untuk kehidupan sehari-hari, untuk memberi lapangan pekerjaan bagi beberapa orang, dan dilain sisi juga dapat membantu membersihkan lingkungan dari limbah anorganik.

\section{C.1 Persamaan dan Perbedaan Pengepul Barang Bekas dengan Kolektor Barang}

Masih ada banyak orang yang tidak dapat membedakan antara pengepul barang bekas dan kolektor barang. Disini kita akan mempelajari apa perbedaan dan kesamaan pengepul barang bekas dengan kolektor barang. Persamaannya hanya sama-sama mengumpulkan barang bekas, sedangkan perbedaananya sebagai berikut.

\section{C.2 Pengepul barang bekas}

pengepul barang bekas adalah orang yang mengepul atau menampung barang bekas di suatu tempat yang bertujuan untuk dijual kembali jika sudah terkumpul banyak dan sudah cukup untuk memenuhi kapasitas pengiriman. Jenis barang bekas yang di kumpulkan atau di tampung adalah sampah nonorganik seperti besi tua, limbah/sampah kertas dan plastik, dimana sampah plastik dan sampah lainnya tersebut dikumpulkan dan dipilah-pilah sesuai jenis agar dapat dikirim ke pabrik daur ulang.

Kegiatan ini bertujuan untuk mencari keuntungan berupa materi untuk kehidupan seharihari, untuk memberi lapangan pekerjaan bagi beberapa orang, dan dilain sisi juga dapat membantu membersihkan lingkungan dari limbah anorganik. Didalam pekerjaan ini terdapat transaksi jual beli yang cukup sering terjadi disetiap harinya. Seperti pembelian dagangan ( barang bekas ) dari para pelanggan ( pencari barang bekas yang menyetorkan barang tersebut ke UD AJENG ) ataupun adanya penjualan barang dagang ( barang bekas ).

Barang bekas yang dibeli dari pelanggan akan dipilah lagi sesuai jenis barangnya. Maksudnya seperti besi tua memiliki 3 golongan yaitu besi tebal / besi super, besi biasa atau besi 1 , dan besi 2 / sepeda. Mengapa dipilah pergolongan? Dipilah pergolongan karena harga pergolongan berbeda. Harga pembelian pabrik yang mengolah barang bekas menjadi patokan 
harga semua pengepul barang bekas. Jika harga dipabrik menurun semua pengepul barang bekas juga akan menurun. Untuk mencari keuntungan dalam bidang ini sangat sulit, karena jika kita membeli barang dagangan terlalu murah para pelanggan akan menjual barang dagangannya ke pengepul barang bekas yang lain. (Sutarmin \& Budiarti, 2020)

UD AJENG menjual barang dagangannya kepada pengepul barang bekas yang lebih besar untuk diproses menggunakan alat berat. Mengapa tidak langsung dikirim ke pabrik langsung? Karena menurut pemilik UD AJENG mengirim sendiri barang ke pabrik lebih sedikit untuk mendapat keuntungan. Adanya potongan berat barang yang disetor dipabrik harus ditanggung UD AJENG setiap pengiriman membuat UD AJENG memilih mencari orang lain yang ingin mengambil barang dagangannya untuk disetorkan ke pabrik pengolahan barang bekas. Walaupun harga yang ditawarkan orang lain tersebut sedikit lebih murah dari harga pabrik barang bekas, tetapi paling tidak UD AJENG tidak harus mendapatkan potongan setiap pengiriman. Karena potongan berat barang yang akan terjadi dipabrik akan ditanggung oleh orang lain yang mengambil barang dagangan dari UD AJENG tersebut.

Semua barang dagangan hampir sama cara penjualannya, kecuali bahan plastik. Barang bekas jenis platik akan dipilah terlebih dahulu oleh karyawan di UD AJENG dan akan disetorkan kepenggiling plastik, baru oleh sipemilik penggiling plastik akan dikirim ke pabrik yang mengolah barang bekas jenis plastik. Barang bekas jenis plastik lebih banyak golongannya, seperti aqua, $\mathrm{AB}$, pet, curigen, warna, dan hitam. Tetapi nama golongan ini biasanya tidak sama disetiap pengepul barang bekas.

\section{C.3 Kolektor Barang Antik}

Barang antik kerap dijadikan dekorasi rumah untuk mempercantik ruangan dengan sentuhan vintage. Selain dekorasi, barang antik juga kerap dikoleksi oleh sebagian orang. Tak heran, harganya terus melambung dari tahun ke tahun. Bahkan, para kolektor barang antik tak segan-segan mengeluarkan uang hingga miliaran rupiah untuk membelinya. Untuk itu, banyak orang yang kini semakin tertarik mengoleksinya agar bisa dijual kembali saat harganya mahal. Ada beberapa barang yang dapat dijual dengan harga yang tinggi, berikut 13 barang antik yang bernilai jual tinggi:

1. Uang kuno 
Uang kuno selalu menjadi barang antik yang bernilai jual tinggi dari tahun ke tahun. Sebab, setiap negara pasti akan selalu mengganti mata uangnya selama periode tertentu. Begitu juga dengan mata uang Indonesia mengalami perubahan dari tahun ke tahun. Dalam setiap edisi, uang kertas selalu hadir dengan warna dan desain yang berbeda. Hal itu membuat uang lama yang sudah tidak beredar menjadi barang antik yang menarik untuk dikoleksi. Nilai sejarah yang terkandung dalam selembar mata uang kuno pasti sangat tinggi.Uang kertas kuno nominal Rp 5.000 tahun 1958 kini memiliki nilai jual yang tinggi karena nilai historis yang dimiliki. Uang ini kini dijual di Bukalapak dengan harga mulai Rp 2.000.000.

\section{Dakon}

Dakon merupakan permainan untuk anak-anak perempuan di masa lampau. Biasanya dakon dimainkan oleh dua anak perempuan seperti permainan congklak. Permainan dakon berbentuk papan panjang dengan beberapa cekungan lubang. Terdapat dua cekungan lubang besar di kedua sisinya. Pada zaman dahulu, biji dakon terbuat dari biji sirsak.Papan dakon lawas kini banyak diminati kolektor barang antik karena bentuknya yang unik. Terlebih lagi, kini tidak ada lagi papan dakon yang terbuat dari kayu. Jika kamu memilikinya di rumah, kamu bisa menjualnya di marketplace mulai dari harga Rp1 jutaan lho.

\section{Guci Antik}

Barang yang satu ini kerap diidentikkan dengan barang antik yang bernilai jual tinggi. Guci antik yang berasal dari zaman dahulu kerap dihargai dengan angka yang besar. Salah satunya adalah guci kecil yang berasal dari Dinasti Qing ini merupakan peninggalan Kaisar Qianlong. Meski bentuknya kecil, guci tersebut rupanya menjadi guci termahal di dunia lho. Ditemukan di sebuah rumah sederhana di London, guci setinggi $40 \mathrm{~cm}$ ini terjual seharga 50 juta Euro atau sekitar Rp 612 miliar dalam sebuah lelang.

\section{Pemutar Piringan Hitam}

Pemutar piringan hitam bisa dibilang sebagai benda yang mewah di masa lampau. Tak heran, kalau barang ini hanya dimiliki oleh segelintir orang kaya pada zamannya. Alat yang digunakan untuk mendengarkan musik ini masih terus diburu loh hingga sekarang. Meski kini sudah ada alat yang lebih modern, pemutar piringan hitam memiliki nilai historis dan seni tersendiri. Tak ketinggalan, banyak pula yang kerap membeli pemutar piringan hitam bersama 
vinyl-nya. Jika kamu ke pasar barang antik, maka harganya akan cukup mahal, yakni mulai dari Rp1 juta hingga Rp10jutaan.

\section{Replika kendaraan}

Salah satu barang antik yang juga kerap diminati kolektor adalah replika atau miniatur kendaraan. Tak heran, banyak kolektor miniatur ini yang berburu hingga ke luar negeri untuk mendapatkannya. Harganya pun bervariasi, mulai dari ratusan ribu hingga ratusan juta rupiah.

\section{Perabot Antik}

Tak hanya dapat dikoleksi, perabot antik juga bisa digunakan pada hunianmu. Perabot ini akan cocok untuk kamu yang memiliki hunian bergaya klasik. Beberapa barang antik yang kerap digunakan di rumah seperti lemari, kursi, hingga meja. Namun, sebelum memutuskan menggunakan perabot antik, pastikan kamu juga sudah siap untuk merawatnya. Dengan begitu, perabot antik itu akan tetap awet dan dapat dijual sewaktu-waktu saat harganya tinggi.

\section{Cangkir Antik}

Banyak orang yang kerap menggunakan cangkir atau cawan antik sebagai dekorasi untuk hunian, Umumnya, cawan antik ini terbuat dari keramik dengan ukiran yang cantik dan memiliki nilai sejarah yang tinggi. Kamu dapat memajangnya di dinding atau disimpan di lemari kaca sebagai hiasan. Harga yang ditawarkan untuk cawan antik ini beragam, mulai dari ratusan ribu rupiah hingga ratusan miliar rupiah.

\section{Jam Dinding Kuno}

Jam dinding kuno ini biasanya memiliki ukuran yang cukup besar dan diletakkan di area yang bisa dilihat banyak orang. Terdapat beragam material yang digunakan untuk jam dinding ini, mulai dari kayu, besi, hingga emas. Keberadaan jam dinding ini akan membuat rumahmu terkesan classy dan mewah.Selain itu suara unik dari jamnya pun beraneka ragam, mulai dari suara lonceng sampai suara menyerupai gong. Harga jam dinding kuno bisa mencapai angka puluhan miliar rupiah tho tergantung dari nilai sejarahnya.

\section{Barang Elektronik Tempo Dulu}


Kini, banyak orang yang kembali tertarik dengan barang elektronik tempo dulu. Salah satunya adalah kembali populernya kamera analog hingga radio. Meski tak bisa digunakan, barang-barang ini kerap dijadikan pemanis ruangan di rumah. Jenis benda ini seperti simbol perkembangan teknologi dari masa ke masa. Selain dipajang di lemari hias, banyak pula yang menjualnya kembali karena nilai jualnya yang tinggi. Salah satu kamera antik berjenis Leica O Series bahkan pernah terjual dengan harga yang fantastis, yakni Rp40,5 miliar pada 2018 silam.

\section{Porselen Antik}

Porselen kuno juga identik dengan barang antik yang mempunyai nilai jual yang fantastis. Salah satunya adalah porselen cantik yang dibuat sekitar tahun 1736 1795. Setidaknya, porselen ini telah ada selama 224 - 283 tahun hingga saat ini.Usianya yang sudah tua membuat porselen ini memiliki daya tarik, terutama karena desainnya yang cantik. Dengan paduan warna putih, biru, dan merah muda, porselen ini dihargai hingga Rp230 miliar.

\section{Buku Antik}

Benda antik selanjutnya yang memiliki nilai jual tinggi adalah buku antik. Terlebih lagi jika penulis buku cukup populer pada masanya. Salah satunya adalah buku karya Leonardo Da Vinci yang berjudul Codex Leicester. Buku yang ditulis dengan tangan itu memiliki nilai jual yang sangat tinggi. Bahkan, buku tersebut menarik perhatian Bill Gates yang membeli buku ini sekitar Rp442 miliar pada tahun 1992.

\section{Lukisan Antik}

Lukisan menjadi salah satu karya seni yang mempunyai nilai jual yang tinggi, terlebih lagi jika mempunyai nilai historis. Selain menjadi koleksi yang bernilai seni tinggi, lukisan juga kerap digunakan sebagai dekorasi rumah yang cantik.Kamu bisa menyelesaikan jenis lukisan dengan interior rumah agar tampak serasi. Lukisan kuno dengan nilai historis yang tinggi harganya bisa mencapai ratusan miliar lho. Salah satunya adalah lukisan berjudul Christ Mocked karya seniman Italia, Cimabue. Lukisan ini berhasil terjual di tempat pelelangan dengan harga US\$26 juta atau sekitar Rp354 miliar.

\section{Perangko}


Siapa yang sangka kalau perangko masuk ke dalam jajaran barang antik yang memiliki nilai jual tinggi. Meski sudah jarang digunakan orang untuk mengirim surat, banyak orang yang kini mulai mengoleksinya. Bahkan, belum lama ini ada sebuah perangko dari era Victoria yang dihargai hingga Rp7 miliar lho.

Kolektor Barang Antik terkadang mencari barang-barang antik ke tukang loak ataupun ke pengepul barang bekas. Kolektor barang antik biasanya mencari barang-barang antik untuk pajangan dan mempercantik rumah, tetapi juga banyak kolektor barang antik yang menjual kembali barang-barang antiknya dengan harga berkali-kali lipat. Bentuk toko atau tempat penjualan barang antik lebih mirip dengan pameran seni. Yang dimaksud adalah penataan barang-barang antik dengan klasik ataupun menyesuaikan barang antik satu dengan barang antik lainnya.

Cara jual beli di kolektor barang antik pastinya berbeda dengan cara jual beli pengepul barang bekas. Harga yang ditawarkan kolektor barang antik tidak ada batasan, dan harga jual lebih ke sepakatan penjual dan pembeli.

\section{METODE PENELITIAN}

\section{A. Jenis Penelitian}

Jenis penelitian deskriptif kualitatif merupakan sebuah metode penelitian yang memanfaatkan data kualitatif dan dijabarkan sejara deskriptif. Jenis penelitian deskriptif kualitatif kerap digunakan untuk menganalisis kejadian, fenomena, atau keadaan secara sosial. Jenis penelitian deskriptif kualitatif menafsirkan dan menguraikan data yang ada bersamaan dengan situasi yang sedang terjadi. Penelitian ini juga mengungkapkan sikap, pertentangan, hubungan serta pandangan yang terjadi pada sebuah lingkup responden.

\section{A.1 Sampel}

Sampel adalah cara pengumpulan data apabila yang diselidiki adalah elemen sampel dari suatu populasi. (Supranto et al., 2009)

Sampel dalam penelitian ini adalah salah satu pengepul barang bekas di Desa Bandung, Kecamatan Bandung Kabupaten Tulungagung. 


\section{A.2 Tempat dan Waktu Penelitian}

Penelitian ini dilakukan di Desa Bandung Kecamatan Bandung Kabupaten Tulungagung. Penelitian ini dilakukan pada bulan Oktober - Desember 2021.

\section{A.3 Prosedur Penelitian}

1. Melakukan survey awal pengepul barang bekas di Desa Bandung

2. Mengumpulkan data yang diperlukan

3. Mengelola data yang telah dikumpulkan

4. Menarik kesimpulan dan saran

\section{A.4 Objek Penelitian}

Objek penelitian sasaran untuk mendapatkan tujuan mengenai suatu hal yang akan dibuktikan secara objektif. Dalam objek penelitian ini yang digunakan kepatuan wajib pajak, metode pembayaran pajak.

\section{A.5 Metode Pengumpulan Data}

Metode dalam mengumpulkan data yang kami gunakan dalam penelitian ini adalah dengan cara melakukan wawancara dengan narasumber yaitu pemilik pengepul barang bekas di Desa Bandung. Metode analisis data yang digunakan dalam penelitian adalah analisis dekriptif kualitatif. Dalam penelitian ini bertujuan untuk menganalisis pajak penghasilan orang pribadi yaitu kepatuhan wajib pajak

\section{A.6 $\underline{\text { Sumber Data }}$}

Sumber data yang digunakan dalam penelitian ini adalah data primer. Data primer, merupakan sumber data penelitian yang diperoleh secara langsung dari sumber asli atau tidak melalui media perantara.

\section{E. PEMBAHASAN}


Indonesia menghasilkan 67,8 juta ton sampah pada 2020. Berdasarkan data Kementerian Lingkungan Hidup dan Kehutanan (KLHK), 37,3\% sampah di Indonesia berasal dari aktivitas rumah tangga. Industri perdagangan di Indonesia saat ini semakin berkembang dengan semakin banyaknya usaha-usaha baru dibidang perdagangan, khususnya pengepul barang bekas di berbagai tempat. Kegairahan para pengusaha pengepul barang bekas untuk berlomba-lomba menanamkan modal mereka dalam pembukaan usaha pengepul barang bekas tidaklah sulit untuk dipahami. Dengan banyaknya sampah-sampah anorganik yang semakin banyak ditemukan diberbagai tempat, membuat para pengusaha yakin dengan usaha dibidang ini. Namun dengan makin maraknya pengepul barang bekas yang berdiri dapat secara perlahan meningkatkan persaingan antara pengepul barang bekas. Namun dalam iklim usaha yang tidak sehat berlaku hukum rimba. Siapa yang kuat dialah yang keluar sebagai pemenang. Sudah banyak contoh pengepul barang bekas di Kabupaten Tulungagung yang merugi dan akhirnya bangkrut atau gulung tikar, karena ketatnya persaingan harga barang bekas. Para pengusaha harusnya dapat berfikir terlebih dahulu sebelum memulai usaha yang akan mereka bangun. Dengan menggunakan analisis SWOT dapat mengurangi persentase kesalahan pemilihan memalai usaha. SWOT adalah singkatan dari Strengths (kekuatan), Weaknesses (kelemahan), Opportunities (peluang), dan Threats (ancaman) .(Sutarmin \& Budiarti, 2020) Analisis SWOT mengatur kekuatan, kelemahan, peluang, dan ancaman utama Anda ke dalam daftar yang terorganisir dan biasanya disajikan dalam bilah kisi-kisi yang sederhana. Strengths (kekuatan) dan Weaknesses (kelemahan) adalah berasal dari internal perusahaan Anda. hal-hal yang dapat Anda kontrol dan dapat berubah. Contohnya termasuk siapa yang ada di tim Anda, paten dan properti intelektual Anda, dan lokasi Anda.Opportunities (peluang) dan Threats (ancaman) adalah hal eksternal yang mempengaruhi bisnis atau hal-hal yang terjadi di luar perusahaan Anda pada pasar yang lebih besar. Anda dapat memanfaatkan peluang dan melindungi dari ancaman, tetapi Anda tidak dapat mengubahnya. Contohnya termasuk pesaing, harga bahan baku, dan tren belanja pelanggan. Sasaran utama para pengepul barang bekas dalam mengembangkan usahanya yakni pada daerah yang berkembang karena dianggap cukup mudah dalam memasuki pasarnya.

Salah satu daerah berkembang di Jawa Timur yakni Kabupaten Tulungagung yang cukup banyak memiliki populasi penduduk, dan terus meningkat seiring berjalannya waktu. Salah satu daerah/desa Bandung Kec. Bandung yang merupakan salah satu kawasan padat penduduk, 
hal ini mempengaruhi banyaknya sampah anorganik yang dihasilkan oleh masyarakat setiap harinya. Hal tersebut banyak menjadi incaran para pengepul barang bekas untuk membuka usaha dikawasan tersebut, karena sampah anorganik semakin hari semakin meningkat. Sebagian besar masyarakat golongan kebawah, pastinya akan tergiur untuk mengumpulkan barang-barang bekas untuk dijual ke pengepul. Melihat hal tersebut, pemikiran pengusaha pasti usaha ini akan mudah untuk dikelola dan akan memenuhi target yang dibayangkan. Tetapi banyak pengusaha yang lupa untuk menghitung peluang keberhasilan dan hanya berfikir tentang keberhasilan. Karena dasarnya sudah banyak pengepul barang bekas yang memiliki pelanggan tetap, dan itu akan berpotensi tidak dapat berkembangnya pengepul barang bekas baru. Pengepul barang bekas semakin banyak di temui di desa Bandung dengan akses yang mudah.

Berkurangnya penghasilan para pemilik pengepul barang ini mempengaruhi kepatuhannya dalam pembayaran Pajak Penghasilan Badan dari penghasilannya. Pajak penghasilan pasal 23 (PPh Pasal 23), yaitu pajak penghasilan yang dikenakan atas penghasilan Wajib Pajak Dalam Negeri atau Bentuk Usaha Tetap yang menerima atau memperoleh penghasilan yang berasal dari modal, penyerahan jasa, atau penyelenggara kegiatan selain yang telah dipotong pajak sebagaimana dimaksud dalam PPh Pasal 21. (Walandouw, 2013)

Dengan alasan pendapatan yang diperoleh tidak tetap disebabkan oleh salah satunya persaingan antar pengepul barang bekas membuat pemilik usaha kadang memilih untuk tidak membayar Pajak Penghasilan Badan.

Alasan lain yang mendominasi yakni kurangnya pengetahuan akan Pajak Penghasilan Badan. Minimnya pengetahuan akan Pajak Penghasilan Badan membuat banyak pengusaha pengepul barang bekas juga tidak mengetahui secara pasti akan kewajiban pembayaran pajak atas penghasilannya. Dan banyak pemilik usaha pengepul barang bekas merasa sudah membayar pajak, namun setelah ditelusuri tenyata pajak yang dibayarkan hanyalah pajak bangunan / Pajak Bumi dan Bangunan. Hal ini seharusnya menjadi perhatian petugas pajak di Kab. Tulungagung untuk melakukan penyuluhan dan sosialisai mengenai Pajak Penghasilan Badan kepada para pemilik usaha pengepul barang bekas agar pengetahuan akan pajak meningkat dan menambah kepatuhan akan pembayaran pajak meningkat. (Ghina et al., 2020) 
Pemerintah daerah juga seharusnya juga lebih memperhatikan usaha pengepul barang bekas ini dengan cara seperti melakukan pembinaan usaha, peminjaman modal usaha, dan penyuluhan secara rutin terhadap pengepul barang bekas untuk mengetahui tingkat pendapatannya. Dukungan dari pemerintah sendiri dapat memberikan dampak yang besar akan berkembanganya usaha pengepul barang bekas ini hingga secara tidak langsung dapat mempengaruhi perkembangan dan pendapatannya.

Pajak usaha pengepul barang bekas Perlakuan pajak untuk pengepul barang bekas akan sama seperti UMKM, yaitu menggunakan skema Pajak Penghasilan (PPh) pasal 23. Dalam artian, besaran pajak dihitung dengan cara mengalikan besaran peredaran (omzet) dalam satu tahun pajak. Hanya bisa digunakan bagi usaha pengepul barang bekas yang memiliki omset kurang dari Rp 4.800.000.000 dalam satu tahun pajak. Penghitungan pajak usaha pengepul barang bekas yang memiliki omzet kurang dari Rp 4.800.000.000 dalam satu tahun pajak adalah 0,5\% dari omzet selama satu tahun pajak. Peraturan Pemerintah Nomor 23 Tahun 2018 Tentang Pajak Penghasilan pasal 23 atas Penghasilan dari Usaha yang Diterima.

\section{F. PENUTUP}

\section{A. Kesimpulan}

Berdasarkan penelitian, kesimpulan dari hasil penelitian

1. Dengan adanya pengusah-pengusaha baru diusaha pengepul barang bekas memiliki dampak negatif terhadap omset, pendapatan, dan jumlah pelanggan pada usaha pengepul barang bekas UD AJENG. Penurunan omset pada pengepul barang bekas UD AJENG kurang lebih sebesar 25\%-50\%. Pendapatan pada pengepul barang bekas UD AJENG sebelum hadirnya pengusah-pengusaha baru dibidang pengepul barang bekas di Kecamatan Bandung cukup stabil, terlihat dengan persaingan antar pengepul barang bekas, dan tidak begitu berpengaruh terhadap pendapatan UD AJENG. Bahkan hal inilah menjadi tolak ukur untuk memenuhi kebutuhan keluarga dari usaha tersebut, terlebih mata pencaharian utama masyarakat di Desa Bandung adalah toko-toko yang pasti memiliki barang bekas yang dapat ditampung oleh pengepulan barang bekas UD AJENG. Selain penurunan omset dan 
pendapatan, usaha pengepulan barang bekas UD AJENG juga mengalami penurunan jumlah pelanggan.

2. Pengetahuan akan Pajak penghasilan badan para pemilik pengepulan barang bekas di Desa Bandung masih dibilang minim, sehingga membuat kedisiplinan dalam membayarkan pajak masih belum maksimal.

3. Selain itu, pendapatan yang kian menurun membuat para pemilik pengepul barang bekas di Desa Bandung menjadi enggan menyisihkan penghasilannya untuk membayar pajak.

\section{B. Saran}

1. Bagi pelaku usaha pengepul barang bekas, sebaiknya melakukan Rebranding bisnis ini menjadi bisnis yang kekinian mengikuti era digital yang berkembang. Seperti melakukan promo di Social media, mengemas usaha ini menjadi usaha yang terlihat modern. Sehingga dapat menjangkau target market yang lebih luas. Setiap kegiatan rumah tangga produksi maupun konsumsi pasti memiliki barang bekas pakai. Hal itu dapat di jadikan sebagai ladang bisnis bagi usaha pengepul barang bekas, semua itu tergantung bagaimana sistem jemput bola yang di lakukan oleh usaha tersebut

2. Untuk Pemerintah daerah seharusnya juga lebih memperhatikan usaha pengepul barang bekas ini dengan cara seperti melakukan pembinaan usaha, peminjaman modal usaha, dan penyuluhan secara rutin terhadap pengepul barang bekas untuk mengetahui tingkat pendapatannya. Dukungan dari pemerintah sendiri dapat memberikan dampak yang besar akan berkembanganya usaha pengepul barang bekas ini hingga secara tidak langsung dapat mempengaruhi perkembangan dan pendapatannya

3. Sistem perpajakan di Indonesia yang menggunakan Self Assement System ini memang memberikan kebebasan bagi wajib pajak orang pribadi untuk menghitung, menetapkan dan melaporkan sendiri pajak penghasilannya, akan tetapi dengan sistem perpajakan seperti ini wajib pajak harus lebih ditingkatkan kesadaran dan pemahaman mengenai pentingnya pemenuhan pajak serta mengenai penghasilan seperti apa yang merupakan objek pajak penghasilan. 


\section{DAFTAR PUSTAKA}

Fadhillah, M. R., \& Andi, A. (2016). Kesadaran Wajib Pajak, Kegiatan Sosialisasi Perpajakan, Pemeriksaan Pajak Dan Penagihan Pajak Terhadap Penerimaan Pajak Penghasilan Badan Pada Kantor Pelayanan Pajak Pratama Tigaraksa. Jurnal Riset Akuntansi Terpadu, 9(1), 27-52. https://doi.org/10.35448/jrat.v9i1.4281

Ghina, A., Fadhilah, A. T., \& Hafsari, E. I. (2020). Intensifikasi Pajak Dalam Penerimaan Pajak Penghasilan Wajib Pajak Badan. Jurnal Ilmiah Manajemen, Ekonomi, Dan Akuntansi, 4(3), 63-73.

Halim, A., Bawono, I. R., \& Dara, A. (2016). Perpajakan (Konsep, Aplikasi, Contoh, dan Studi Kasus) Dasar-Dasar Perpajakan. In Penerbit Salemba Empat (Vol. 7, Issue 9).

Prabowo, R. G. M. (2019). MEKANISME PPN DAN PPnBM. https://doi.org/10.31227/osf.io/shqmg

R. Wandira 2017 Pajak, P. ini bertujuan untuk menguji dan menganalisis pengaruh pemeriksaan, Dan, sanksi perpajakan dan self assessment system terhadap kepatuhan W. P., \& ... dampaknya terhadap penerimaan pajak. S. penelitian ini adalah A. (2016). $R$ Wandira - 2017 - repository.unpas.ac.id. July, 1-23.

RAHARJO, A. (2013). ANALISIS DETERMINAN PENERIMAAN PAJAK PENGHASILAN DI INDONESIA. Universitas Sumatera Utara.

Resmi, S. (2017). Perpajakan teori \& kasus. Salemba Empat. Jakarta.

Supranto, Ruslan, M. H., Alghoul, M. A., Sulaiman, M. Y., Zaharim, A., \& Sopian, K. (2009). Estimating the a solar assisted drying system capacity for marine products. Proceedings of the 3rd WSEAS International Conference on Energy Planning, Energy Saving, Environmental Education, EPESE '09, Renewable Energy Sources, RES '09, Waste Management, WWAI '09, 331-335.

Susi Dwimulyani, M. M. (2014). Dampak Undang-Undang No. 36 Tahun 2008 tentang Pajak Penghasilan pada Manajemen Laba: Investigasi pada Perusahaan Publik dengan Struktur Kepemilikan Ultimat. Universitas Gadjah Mada. 
Sutarmin, -, \& Budiarti, W. (2020). Karakteristik Umkm Pengepul Dan Bandar Barang Bekas Pendekatan Fenomenologis (Studi Kesuksesan Orang Madura Sebagai Pengepul, Bandar barang Bekas Di Keputih Surabaya). Jurnal Studi Manajemen Dan Bisnis, 7(2), 141151. https://doi.org/10.21107/jsmb.v7i2.9138

Walandouw, P. (2013). Analisis Perhitungan Dan Pelaporan Pph Pasal 23 Dan Pph Pasal 25. Jurnal Riset Ekonomi, Manajemen, Bisnis Dan Akuntansi, 1(3), 987-997. https://doi.org/10.35794/emba.v1i3.1908 